uwikłaniach życiowych, tak bardzo podobnych do naszych. Należy więc podziękować ludziom związanym bliżej ze zmarłym $\mathrm{H}$. Chadwickiem oraz wydawnictwu z Oksfordu, za znalezienie i udostępnienie jego manuskryptu dla szerokiego grona zainteresowanych.

ks. Ryszard Groń - Wrocław, PWT

\begin{abstract}
Ks. Józef POCHWAT MS, „Misterium iniquitatis”. Studium tajemnicy nieprawości w dzielach Jana Kasjana (360-435), Kraków 2012, Wydawnictwo La Salette, ss. 384.
\end{abstract}

Na rynku wydawniczym można spotkać coraz częściej tytuły, które związane są z tematyką świata nadprzyrodzonego, a w szczególny sposób z działaniem złego ducha wobec człowieka. Obok wywiadów i opisów osobistych doświadczeń trudno niekiedy znaleźć pogłębione opracowania teologiczne poświęcone powyższym zagadnieniom. Brakowało dotąd na polskim gruncie specjalistycznych monografii prezentujących, jak ta kwestia przedstawiała się w epoce Ojców Kościoła. Za swoisty punkt wyjścia w tym zakresie należy uznać 17 . tom znanej serii wydawniczej redagowanej przez ks. prof. Henryka Pietrasa SJ, pt. Demonologia w nauce Ojców Kościoła (Kraków 2000), zawierający materiały z sesji naukowej zorganizowanej przez Sekcję Patrystyczną przy Komisji ds. Nauki Katolickiej Konferencji Episkopatu Polski, która odbyła się w Siedlcach w dniach 21-22 września 1998 roku. Do tego tomu został dołączony traktat Hipolita O Antychryście w przekładzie Stanisława Kalinkowskiego (ss. 109-148). Swoistą kontynuację badań zaprezentowanych w powyższym opracowaniu stanowi recenzowana książka ks. Józefa Pochwata MS, pt. „,Misterium iniquitatatis”. Studium tajemnicy nieprawości $w$ dziełach Jana Kasjana (360-435). Jest to pozycja o tyle cenna, iż przedstawia nauczanie autora, którego można nazwać łącznikiem między wschodnią i zachodnią myślą patrystyczną. Urodzony na Wschodzie, późniejsze swoje życie łączy z Zachodem, potrafiąc umiejętnie inkulturować swoje wschodnie doświadczenia. Twórczość Jana Kasjana pozwala spojrzeć szerzej na problemy ówczesnego świata chrześcijańskiego, co Autor monografii dobrze uwypukla.

Ks. J. Pochwat podzielił swoją książkę na dwie zasadnicze części: historyczną i teologiczną. W części historycznej (ss. 21-81) autor pragnie zapoznać czytelnika z dziejami Kościoła w Galii na przełomie IV i V w., przedstawiając tło dziejowe, a więc wojny z barbarzyńcami w tym okresie oraz prezentację problematyki społecznej i sytuacji Kościoła, zwracając przy tym szczególną uwagę na herezje i prześladowania oraz tworząc zarys genezy monastycyzmu chrześcijańskiego w Galii (rozdział I, ss. 22-49). W tej części również została przedstawiona szczegółowa biografia Jana Kasjana, co jest uzasadnione tym, że - jak podaje sam autor - ,jest to jedna z najbardziej tajemniczych postaci pośród pisarzy i Ojców Kościoła" (s. 50). Ks. J. Pochwat, pisząc o życiu i działalności Jana Kasjana, dokonuje niemalże dziennikarskiego śledztwa, co pozwala czytelnikowi, znającemu 
pobieżnie życiorys, łatwiej zrozumieć charakter nie tylko pism, ale również myśli pisarza z Marsylii (rozdział II, ss. 50-81).

W części teologicznej (ss. 83-327), którą można uznać za istotną partię książki, ks. J. Pochwat przedstawia tajemnicę nieprawości w nauczaniu Jana Kasjana. Rozdział I (ss. 83-141) jest przedstawieniem demonologii w nauczaniu mnicha marsylskiego. Walorem tego rozdziału jest nie tylko ukazanie nauczania Kasjana na temat tej kwestii, ale również rozumienia tego zagadnienia w okresie, w którym Kasjan żył. Autor podkreśla, że temat ten jest „tajemniczy, mało znany i trudny do zbadania" (s. 140). Ks. J. Pochwat koncentruje uwagę na tajemnicy szatana i demonów, przedstawia imiona szatana oraz jego obecność w historii zbawienia. Omawia naturę złych duchów oraz prawdopodobnie pierwszą próbę wprowadzenia hierarchicznego zróżnicowania na gruncie demonologii wraz z ukazaniem rywalizacji pomiędzy złymi duchami. Ostatnią część tego rozdziału nazwać można duszpasterska, gdyż Autor pisze o działaniu złych duchów i ich zgubnego wpływu wobec człowieka, akcentując kwestię zakresu poznania człowieka przez złe duchy.

W rozdziale II (ss. 142-230) zostają przedstawione poglądy Jana Kasjana na temat oddziaływania złych duchów na człowieka. Czytelnik, który dziś wiele słyszy na temat opętań we współczesnych czasach, może zapoznać się ze świadectwem mnicha marsylskiego, który przytacza znane mu historie z życia anachoretów (często sam był ich świadkiem), związane z opętaniem tak duchowym, jak i cielesnym. Ks. J. Pochwat referuje myśl Jana Kasjana, który podkreśla, że złe duchy oddziałują na człowieka nieustannie przez podsuwanie pokus, pobudzających do złego. Prowadzi to do powstania wad, które są stałą dyspozycją woli człowieka do spełniania czynów moralnie złych. Wady rodzą grzechy, czyli postawy polegające na mniej lub bardziej świadomym przekraczaniu norm moralnych lub religijnych. W ostatniej części czytelnik może zapoznać się, jak Kasjan rozumie grzech, jaka jest jego natura, rodzaje oraz w jaki sposób opanowuje on człowieka i do jakich skutków doprowadza.

W rozdziale III (ss. 231-327) ks. J. Pochwat stara się usystematyzować nauczanie mnicha z Marsylii o wybawieniu człowieka spod działania złego ducha oraz o uwolnieniu od wad i grzechów. Wybawiającym człowieka - jak przypomina Kasjan - jest Chrystus, który dał przykład tego na górze kuszenia i tylko On może to uczynić. Autor podaje świadectwa zaczerpnięte przez autora Collationes ze Starego Testamentu i Ewangelii oraz z listów św. Pawła. Ks. J. Pochwat za Marsylczykiem zwraca uwagę na niebezpieczeństwo, jakie ten widzi w dwóch ruchach heterodoksyjnych: pelagianizmie i nestorianizmie, których przedstawiciele twierdzili, że człowiek sam o własnych siłach może być zbawiony. W ostatniej część tego rozdziału Autor podaje wskazania duchowe, które Jan Kasjan przekazywał w swoich pismach, a w szczególności w Collationes. Szczególna uwaga została zwrócona na nawrócenie i pokutę, które wsparte Bożą łaską pomagają w walce z demonami i dają odporność na ataki zła.

Książka ks. J. Pochwata, opracowana rzetelnie od strony merytorycznej i metodologicznej, odsyłająca do wielu interesujących tekstów źródłowych, jest pozy- 
cją bardzo wartościową przede wszystkim ze względu na podjętą tematykę, która coraz częściej staje w centrum zainteresowania zarówno historyków teologii i duchowości, jak i zwykłych chrześcijan. Oprócz przedstawienia spojrzenia na kwestię opętań i działania złych duchów w okresie IV i V w. Autor przytacza, jakże dziś aktualne, pomoce oraz konkretne rozwiązania dla ludzi, którzy borykają się z takimi samymi bądź podobnymi problemami. Książka ,,Misterium iniquitatis" jest nie tylko książką naukową, ale śmiało może stać się podręcznikiem dla osób, a w szczególności kapłanów, zwłaszcza egzorcystów, którzy podejmują się pracy z osobami dotkniętymi nasilonym oddziaływaniem złego ducha. Również dla wiernych może stać się ona pomocą do codziennej przemiany swojego życia, zawiera bowiem konkretne wskazówki możliwe do wykorzystania w walce duchowej toczonej przez ludzi każdej epoki. Cenną rzeczą jak sam zauważa ks. Pochwat, byłoby w przyszłości zestawienie myśli kilku autorów wczesnochrześcijańskich, działających w różnym czasie i w różnych miejscach, co pozwoliłoby zapoznać się $\mathrm{z}$ tą problematyką $\mathrm{W}$ szerszym porównawczym ujęciu oraz prześledzić rozwój wczesnochrześcijańskiej demonologii i wyeksponować wzajemne wpływy, zależności, a także różnice. Jeden z pierwszych kroków ku takiej syntezie został uczyniony.

ks. Marcin Sobiech - Lublin, KUL

\section{Tomáš ŠPIDLÍK, Peretki Ojców Kościoła, tlum. Andrzej Babuchowski, Warszawa 2010, Wydawnictwo Księży Marianów, ss. 144.}

Autor książki, kard. Tomáš Špidlík SJ, urodził się 17 grudnia 1919 r. w Boskovicach, a zmarł 16 kwietnia 2010 w Rzymie. Studiował na wydziale filozofii na uniwersytecie w Brnie, a w roku 1940 wstapił do zakonu jezuitów w Benešovie koło Pragi. W latach 1942-1945 odbył studia filozoficzne w Velehradzie. Po zakończeniu wojny został wysłany do Maastricht (Holandia) na studia teologiczne. Tam też 22 sierpnia 1949 r. otrzymał święcenia kapłańskie. W 1951 r. został wezwany do Rzymu, aby pracować w Radiu Watykańskim. Przez 38 lat był kierownikiem duchowym Papieskiego Kolegium św. Jana Nepomucena. W 1955 obronił dysertację doktorską w Papieskim Instytucie Wschodnim w Rzymie. Był wykładowcą patrystyki i teologii duchowości wschodniego chrześcijaństwa w wielu uniwersytetach Rzymu i świata, między innymi na Papieskim Instytucie Studiów Wschodnich i Papieskim Uniwersytecie „Gregorianum”. Na emeryturę przeszedł w 1990 r., jednak nie przestał wykładać. Był też konsultorem Kongregacji dla Kościołów Wschodnich. Znany jest jako autor wielu publikacji (ok. 40 książek i 600 artykułów), tłumaczonych na wiele języków.

Wśród nich znajduje się również książka zawierająca wybór najcenniejszych myśli Ojców Kościoła, opatrzonych komentarzem, zatytułowana wymownie $P e$ retki Ojców Kościoła. Sam autor w przedmowie do swojej książki zaznacza, że wpisuje się ona w tradycję wypisów klasztornych, trwająca od czasów średnio- 